\title{
Functional Category of Aspectuality in the Russian And English Languages
}

\author{
Hripsime A. Derdzakyan \\ Yerevan State University of Languages and Social Sciences n.a. V.Ya. Brusov, \\ 42, Tumanyan street, Yerevan, Republic of Armenia, 0002 \\ Corresponding author: d-ripsime@mail.ru
}

\begin{abstract}
This article studies functional and semantic Tense/Aspect complexes in Russian and English, focusing on their similarities and differences. In Russian, Tense-Aspect meanings of the verb forms correlate with the semantic components of Aktionsart, while in English both Imperfective and Perfective aspects of the verb semantics are realized by the constituent category of Tense/Aspect. The inner asymmetry of the verb forms and meanings is acknowledged for each of the contrastive languages, especially for the two languages compared. The material of the study is retrieved from grammar books and manuals and from literary text samples, principally concerns the use of Tense/Aspect forms of the Russian verb and the forms of the English Perfect. The novelty impact of the study is determined by focusing on the irregularity of the aspectual meanings of English Perfect forms and Tense/Aspect forms of the Russian verb, whereas they are mostly due to lexical meanings of the verbs influenced by intralinguistic specificities of the semantics of lexical indicators as well as mechanisms of communication on the whole. Aspectual meanings both for the Perfective and Imperfective Aspect in languages under comparison used to make up lexical and grammatical aspectual categorical complexes. In terms of Aspect and Tense, peculiarities are found as functional and semantic ones, highly dependent on the situation and context of communication, thus involving extralinguistic factors which also concern the extralinguistic environment of Tense/Aspect verbal forms in use. The comparison of functions and the semantics of Aspect and Aktionsart in the Russian language with those of English Perfect asymmetry is proved to emerge, being caused by cross-linguistic structural and typological differences, particularly, the existence or not the similar forms, their varying semantic load, analytical or synthetic tendencies and others. The asymmetry is especially vividly seen translation and lexicographic field to compose varying kinds of bilingual dictionaries.
\end{abstract}

Key words: functional complexes, semantic complexes, Tense/Aspect forms, Aktionsart, asymmetry, aspectual meanings, lexical indicators

\section{Article history:}

Received: 05.08.2020

Accepted: 15.12.2020

(C) Дерцакян Р.A., 2021

This work is licensed under a Creative Commons Attribution 4.0 International License https://creativecommons.org/licenses/by/4.0/ 


\title{
For citation:
}

Derdzakyan, Hr.A. (2021). Functional Category of Aspectuality in the Russian and English Languages. RUDN Journal of Language Studies, Semiotics and Semantics, 12(1), 41-60. doi: $10.22363 / 2313-2299-2021-12-1-41-60$

УДК [811.161.1:811.111]'36/37

\section{Функциональная категория аспектуальности в русском и английском языках}

\author{
P.А. Дерцакян \\ Ереванский государственный университет языков и социальных наук им. В.Я. Брюсова, \\ 0002, Республика Армения, Ереван, ул. Туманяна, 42 \\ d-ripsime@mail.ru
}

\begin{abstract}
Аннотация. Статья посвящена изучению функциональных и семантических комплексов глагола в русском и английском языках, фокусируя внимание на их сходствах и различиях. В русском языке видовременные комплексы значения глагольной формы коррелируют с семантическими составляющими способов глагольного действия, а в английском языке и грамматическая, и лексическая семантика глагола реализуется составной категорией TenseAspect. При этом обнаруживается внутренняя асимметричность глагольных форм и значений для каждого из сопоставляемых языков, а тем более - для двух сравниваемых языков. Материалом исследования послужили видовременные формы русского глагола и формы английского перфекта, извлеченные из грамматических источников, в том числе учебников, и художественных текстов, которые, прежде всего, рассматривают употребление русских видовременных форм и перфекта в английском языке. Новизна определяется выявлением и анализом нерегулярностей соответствий значений английского перфекта и русских видовременных форм, при этом учитывается и фактор их лексических значений, как и специфика семантики внутриязыковых индикаторов и в целом условия коммуникации. В сопоставляемых языках аспектуальные (видовременные) значения формируют лексико-грамматические аспектуальные категориальные комплексы. Их функционально-семантические особенности также обусловлены ситуацией и контекстом общения, которые включают экстралингвистические факторы, обусловливающие экстралингвистическое окружении в процессе употребления видовременных форм. При сопоставлении функций и семантики категорий Aspect (вид) и Aktionsart (способ глагольного действия) в русском языке с аналогичными категориями английского языка отмечается асимметричность, нерегулярность аспектуальных значений английских форм Perfect и видовременных форм русского глагола, что в наибольшей степени обусловлено межъязыковыми структурными и типологическими различиями, аналитическими и синтетическими различиями, как и с точки зрения по-разному семантически нагруженных глагольных форм. Особенно ярко такая асимметрия проявляется в переводе и лексикографии при составлении двуязычных словарей различных типов.
\end{abstract}

Ключевые слова: функциональные комплексы, семантические комплексы, видовременные формы, способы глагольного действия, асимметричность, аспектуальные значения, лексические опоры

\section{История статьи:}

Дата поступления: 05.08.2020

Дата приема в печать: 15.12.2020 


\section{Для цитирования:}

Дериакян P.A. Функциональная категория аспектуальности в русском и английском языках // Вестник Российского университета дружбы народов. Серия: Теория языка. Семиотика. Семантика. 2021. T. 12. № 1. С. 41—60. doi: 10.22363/2313-2299-2021-12-1-41-60

\section{Introduction}

Functional approach to the description and study of language phenomena, represented by a number of linguistic schools, touches upon both lexics and grammar. Primarily, in the sphere of lexical semantics, it is realized within the notion of lexical function (Yu.D. Apresyan, I.A. Mel'chuk $[1 ; 2]$ and others), and in the sphere of grammatical semantics - in the theory of functional grammar (A.B. Bondarko, M.A. Shelyakin [3; 4] and others).

The aim of the article is to establish the common and different spheres of functioning of the semantic complexes of verb forms in the English and Russian languages.

Theoretical provisions are followed by the concrete speech samples, illustrating the asymmetry, non-regularity of the aspectual meanings of Perfect forms and Tense-Aspect form of the Russian verb, thus proving that both in the Russian and in English languages, the aspectual semantics refers to the lexical meanings of verbs and textual function of the verb forms being analyzed.

Being a central category of the language, alongside with the noun the verb bears the main functional load in the formation of the communicative units sentence and utterance, in particular. The verb structures the text as a whole, first of all, in terms of the correlation of the meanings of real time and linguistic time.

In the comparative study of the functional and semantic complexes of the verb their similarities and differences are revealed in the languages under comparison. Thus, in Russian Tense-Aspect meanings of the verb forms are correlated with the semantic components of Aktionsart, while in English both types of the verbal semantics are realized by the constituent category of Tense/Aspect. While an inner asymmetry of the verb forms and meanings is being revealed for each of the contrastive languages contrasting, usually for the two languages under the study.

In course of studying, complex description of Tense-Aspect and aspectual meanings for the opposition «Verb Aspect - Aktionsart» has been presented, the compatibility of the notions «aspect pair — aspectual pair» has been established.

For the purpose of describing functional semantics, the range of meanings of the opposition «Perfective Aspect - Imperfective Aspect» has been revealed, and the range of the main aspectual meanings within the mentioned aspectual opposition as correlated with the semantics of Aktionsart.

For the English Perfect form, a complex categorial approach within the complicated verb category has been proved, and also the range of linguistic means and techniques has been characterized, which allows adequately realize the stated complex of meanings in use. 


\section{Aspectuality of the Russian Verb}

\section{Aspect and Aktionsart}

The morphological category of aspect covers all the complexes of Russian verb forms, first of all finite forms (the conjugated ones), and also the Infinitive, Participle and Gerund. If the external formal indicators of aspect — suffixes and prefixes - due to their very nature belong to the sphere of morphogenesis or partially word-formation, then to speak about inflections is currently not the case. Aspect is characterized as non-inflexional category of the verb, but at the same time, it is a system of the sets of verb forms opposed to each other: sets of verb forms, denoting an action limited and integral (verbs of the Perfective Aspect), and sets of verb forms, devoid of the characteristics of bounded (limited) integral action (verbs of Imperfective Aspect).

Such an opposition inside the category of Aspect is connected with the notion of common aspectual opposition, according to R. Jackobson, which has led to the binary opposition: «forms of the Perfective Aspect (marked category) — forms of the Imperfective Aspect (unmarked category)» [5. P. 213]. But the existence of such correlation, on the one hand, as if proves the symmetry of aspectual forms and their corresponding meanings, first of all, for aspectual pairs and aspectual correlations, and on the other hand, the existence of bi-aspectual and mono-aspectual verbs, on the contrary, allows reveal aspectual paradigm asymmetry, let alone Tense-Aspect correlation. Moreover, the asymmetry is vividly revealed in the sphere of usage, functioning of aspectual forms, along with the sphere of their semantics. See below the Table 1 which rather clearly illustrates the noted phenomenon [6. P. 612]:

Table 1

Types of situations and the use of aspect forms of Russian verb

\begin{tabular}{|l|l|l|l|}
\hline \multirow{2}{*}{ Situation Types } & \multicolumn{2}{|c|}{ Verb Forms } \\
\cline { 3 - 4 } 11. & $\begin{array}{l}\text { Situation of a single } \\
\text { (unrepeated) action }\end{array}$ & $\begin{array}{l}\text { Perfective } \\
\text { use. } \\
\text { Variants: potential, Perfect, } \\
\text { limitive-durative, summary }\end{array}$ & $\begin{array}{l}\text { Imperfective } \\
\text { of use. } \\
\text { Variants: Connotative, } \\
\text { distinctly-continuous }\end{array}$ \\
\hline 22. & $\begin{array}{l}\text { Situation of repeated } \\
\text { action }\end{array}$ & $\begin{array}{l}\text { Illustrative-examplary type } \\
\text { of use: } \\
\text { Variants: potential, perfect }\end{array}$ & $\begin{array}{l}\text { Unlimitive-iterative type of } \\
\text { use. Variants: potential, } \\
\text { (potential-usual and } \\
\text { potential - qualitative), } \\
\text { illustrative-examplary }\end{array}$ \\
\hline 33. & $\begin{array}{l}\text { Situation of continuous } \\
\text { (ongoing) relation }\end{array}$ & - & $\begin{array}{l}\text { Type of use with the meaning } \\
\text { of continuous (ongoing) } \\
\text { relation }\end{array}$ \\
\hline 44. & $\begin{array}{l}\text { Situation of generalized } \\
\text { fact }\end{array}$ & - & $\begin{array}{l}\text { Generalizing-factual type of } \\
\text { use. Variants: negative, } \\
\text { limitive-iterative, perfect, } \\
\text { with the meaning of } \\
\text { «cancelled result» }\end{array}$ \\
\hline
\end{tabular}


According to Table 1, categorial meanings of aspectual forms and types of situations play significant role in understanding the functioning of the Aspect category.

\section{Categorial Meanings of Verb Forms}

According to A.B. Bondarko, categorial meanings of Aspect forms are due to the grammatical system of the language and have some varieties [3. P. 99]: firstly, the general invariant meaning, which irrespective of the opposition Perfective Aspect/Imperfective Aspect, covers all the sphere of functioning of the given form [Ibid.]; secondly, the basic meaning, characterizing «the central sphere of functioning of the given form and combining one or some peripheral meanings», and finally thirdly, a kind of complex, combining invariant and general meanings [Ibid.].

Evidently, in such approach the category of Aspect is structured as a functional-and-semantic field, which has a centre and a periphery, and in relation to other functional-and-semantic fields, it stands out due to its general invariant meaning and a complex of central and peripheral meanings, which are closely interdependent within Aspect.

If those functional and semantic correlations are applicable to both Aspect pairs of the verb, then the vivid marked category of the Perfective Aspect is characterized by the general meaning, combining two features, and, therefore, a complex one: 1 ) the feature of integrity and 2) the feature of limitativenss $[3 ; 7 ; 8]$.

In our point of view, what is essential is the understanding of non-identity of the given features, and their interactions and duality, which, according to A.B. Isachenko, involve «the view on the action»: if integrity is conditioned by the view on the action as if from the outside, externally, then the action «in the process of its development», the possibility of dividing the action into phases «beginning - end - duration» presupposes, that «the speaker is as if inside the process» [9. P. 131-132].

In fact, as A.B. Bondarko notes, the principle of integrity doesn't deny the division into phases, but for the verbs of the perfective aspect it is impossible to single out the phase of duration, the singling out of the beginning is difficult as well, only the phase of the end is evident [3. P. 102]. The integral component of the feature of integrity is «the fullness of the expression of action-state» [10. P. 472; 3. P. 102].

Limitativeness itself, the limits of the integral action, marked as «the feature of limitativeness», builds the complex of general meaning of the perfective aspect up to «the two-featured binominal», while the «limit» is accounted for both lexically and contextually, although it covers all the verbs of perfective aspect in all types of their functioning [3. P. 106; 11].

Thus, the general meaning of the Perfective Aspect once more indicates its markedness in the opposition Perfective Aspect - Imperfective Aspect, in which the member of the Imperfective Aspect, correspondingly, appears unmarked, devoid of the positive features within the general meaning. Such semantic markedness in other types, other structural organization of languages may be specific in other way, i.e. reveal other intra-aspectual systemic meanings. 


\section{Functional Environment of the Aspect Category}

The functioning of grammatical forms and categories depends on a number of factors, which A.V. Bondarko referred to as «types of environment». Speech environment - is the external environment, which is created by the context and speech situation, the conditions and the point of view of the speaker. Systemic language environment, or paradigmatic, internal, is formed considering the environment of language units, categories or their complexes. If the speech situation is created by both lexical and grammatical means of the language, then the internal, paradigmatic environment is based on the lexical and grammatical semantics of linguistic units and categories, on the rules of their combinability, on their lexical realizations. Typical environment of the Aspect category includes the following elements, «the semantics of which interacts with systemic aspectual meanings, influencing on their realization in speech» [3. P. 111], namely:

1) lexical meanings and semantic classes of verbs $[7 ; 12 ; 13]$;

2) 'aktionsarts' and lexical-and-semantic categories of limitive/unlimitive verbs [4];

3) grammatical categories of a particular verb lexeme, which interact with Aspect, for example, Tense, Voice, etc.

4) elements of the environment of the particular verb form, creating relevant aspectual context, e.g., other verb forms, adverbial indicators, identification of subject/object, etc.

\section{Aspect Semantics and Aspectuality}

The notion of Aspectuality, heterogenious by its nature, belongs to the outline content subject-matter. Being one of the most important linguistic categories, reflecting the idea of «inner» time, Aspectuality covers a number of particular meanings, which are in relation of intersection of the meanings of the categories of duration, phases, perfectness, multiplicity, etc. [14. P. 22-29].

At the same time, Aspectuality is closely connected with the categorial meaning of Aspect, which, on the one hand, while forming the centre of functionaland-semantic field, produces functional-and-semantic areas of Aspectuality: limitativeness, duration, phases, multiplicity, perfectness, etc., including actionalness, statalness and relationalness as the specific semantic spheres of verbs, which are studied within the theory of functional grammar. On the other hand, categorial aspectual meanings both for the Perfective and Imperfective Aspect, include the mentioned aspectual complexes.

Thus, there are the actions of two tendencies: centrifugal and centripetal, showing the dynamic processes in relation to the characteristics of the duration of the action or its distribution in time. In this respect the understanding of Aspectuality as «the inner time of the action» approaches to the common definition of aspect, according to B. Comri, «... aspects are various means of considering the internal temporal structure of the situation» [15. P. 3]. 
In this regard, the realization of the semantic potential of the Perfective and Imperfective Aspects of verbs is carried out differently: being a marked member of the opposition, having certain properties, the Perfective aspect shows its properties in the field of Aspectuality clearly and directly, while the Imperfective Aspect, lacking «the positive meaning», according to A.V. Bondarko, i.e. lacking properties, being unmarked, obviously contrasts with the Perfective Aspect semantics, and therefore, it depends mostly on the lexis, context and speech situation.

As an illustration of the given provision, let's refer to the two contrasting aspectual meanings: duration for the verbs of the Imperfective Aspect and perfectness for the verbs of the Perfective Aspect.

\section{Aspectual Sphere: Duration}

The linguistic meaning of duration represents one of the aspects of the broad sense of time, which in the field of Aspectuality it is perceived as the inner duration of the action and is connected with the lexical, word-formational and grammatical semantics of the verb. For example, the lexical meaning of the Russian verbs бедствовать, возиться, ждать, сидеть, etc., supposes the element of the temporal duration.

The Russian verbs of limitive and durative-limitive semantics, such as повозиться, посидеть, проболеть, продержаться, еtc., may combine the meaning of limited duration with that of the weakened intensiveness of the action («not long and at the same time not much, not to a full extent»), however, the feature of duration (limited) of the given category of verbs is expressed clearly and vividly.

«Internal» duration as «the internal time of the action» is accompanied by the means of expressing the external determination of duration. In Russian, they have lexically concrete character: две минутьл, за два года, до вечера, etc., but they contain generalized semantic properties, referring to the sphere of Aspectuality. For example, the extended duration, expressed by the combination of the Imperfective Aspect forms with Russian adverbials, such as долго, два часа, много лет, долго писал (думал, гулял), etc.

Compatibility of the duration indicators, such as долго, три дня, пять лет, etc. mainly with the verbs of the Imperfective Aspect, is due to the absence of the feature of limitativeness in the Imperfective Aspect. Within the Imperfective Aspect it widely realizes the possibility to include the quality of duration of the aspectual characteristics of the action: firstly, the internal duration of the action, connected with the lexical meanings of verbs and mainly with the process semantics of the Imperfective Aspect in such cases as maщuться, взбираться, волочить, (all examples are in Russian), etc.; and secondly, the combinability of the verbs of the Imperfective Aspect correlates with the external determination, indicating the extended duration either lexically or contextually is widely spread. 


\section{Aspectual sphere: Perfectness}

«Perfectness is the semantic category within Aspectuality, characterized by the peculiar temporal ambiguity, combining in one predicative (or folded-predicative) unit two somehow connected with each other temporal plans - preceding and following ones. The connection between these two plans is causitive-consequative in the broadest sense of the word: the preceding action (or broader, the preceding «state of affairs») causes some consequences for the subject of the action, for its object or for the situation as a whole, some «new state» [16. P. 195].

It should be noted, that the later temporal plan in the structure of the bipartite «perfect unity» one way or another is oriented in the flow of time. This plan either includes the time of utterence - and in this case, we have true-perfect meaning, or it takes some other «reference point» — and in this case we speak about temporallyshifted perfect meanings, for example, Pluperfect.

Besides, there is one of the two temporal plans in the focus of attention of a speaker:

1) the state, being considered in relation to the preceding action it caused,

2) the action itself (and, broader, "state of affairs»), referring to some earlier moment in the flow of events, but being considered with respect to its direct or indirect consequences, which are relevant for the future.

In the first case, we deal with Statal Perfect, e.g., Окно открыто/открыли на иельй день вчера вечером (in Russian); in the second case - with Actional Perfect: Окно открыли вчера вечером (in Russian).

In a number of cases Statal and Actional perfects may be demarcated only by involving a broader context, or even they aren't demarcated at all. In this case, we deal with Diffuse perfect, a relative «balance» of the two temporal plans.

For example: Окно открыли или Дом построили (in Russian).

From the point of view of the formal expression, perfectness may be subdivided into explicit and implicit.

Explicit perfectness is presented in the Modern Russian literary language first of all by the predicative participles with $-\mathbf{H} /-\mathbf{T}$, which were plainly qualified as «perfect» by A.A. Shakhmatov [10. P. 486]. When using the term «perfectness» it is necessary to emphasize a kind of defectiveness (incomleteness) of «Shakhmatov's Perfect» in the system of the Russian verb in comparison with the perfect in a number of languages, particularly in the English language, where the form called «Perfect» is considered to be generally accepted.

Let's consider perfectness in combination with the categories of Aspect and Tense of the verb.

a) Peculiarities in terms of Aspect

A.A. Shakhmatov gives examples of Perfect only from the stems of perfective aspect, and indeed, such examples are more typical and frequent. Still along with them participles from the stems of imperfective aspect occur.

Examples: Tротуар здесь мощен плитами. (Cотр. мостили). 
Ваша карта бита. (Comp. была бита).

Дуракам закон не писан. (Comp. не писали).

b) Peculiarities in terms of Tense

In languages with epy developed system of Perfect, this system usually includes the forms, opposed to one another in the category of the so-called deictic time, for example, in English Present Perfect, Past Perfect and Future Perfect, and also corresponding modal forms, Infinitives and others. In the Russian language, «the paradigm of Perfect» can be built, including such forms as будучи построен, был бы построен, (может) быть построен, but in its commonly used elements it is non-parallel to the main verb paradigm [17. P. 151], as opposed to the English language, compare:

Table 2

Regularity of verb forms and their paradigms in the English language

\begin{tabular}{|c|c|c|c|}
\hline \multirow{2}{*}{ Aspect } & \multicolumn{3}{|c|}{ Tense } \\
\hline & Present & Past & Future \\
\hline $\begin{array}{l}\text { Common } \\
\text { Continuous } \\
\text { Perfect }\end{array}$ & $\begin{array}{l}\text { I GO } \\
\text { I AM GOING } \\
\text { I HAVE GONE }\end{array}$ & $\begin{array}{l}\text { I WENT } \\
\text { I WAS GOING } \\
\text { I HAD GONE }\end{array}$ & $\begin{array}{l}\text { I'LL GO } \\
\text { I'LL BE GONE } \\
\text { I'LL HAVE GONE }\end{array}$ \\
\hline
\end{tabular}

In other words, such forms can have both perfect and non-perfect actional semantics, due to which they differ from the forms without the auxiliary verb, specialized on expressing perfectness.

The forms of the future perfective in some contexts may correspond to the «future perfect» in a number of languages, for example:

Когда ты войдешь в комнату, окно уже будет открыто (in Russian).

Here for the actualization of perfect meaning not the participle, but the word уже is essential: Когда ты приедешь, он уже уйдет (in Russian).

For the Past Tense form of the Imperfective Aspect the meaning of perfect traditionally is considered to be less typical. Compare:

1) Я уже скосил траву (значит лужайка хорошо выглядит) - Perfective Aspect, and:

2) Я уже косил траву (значит второй раз косить не нужно) - Imperfective Aspect.

And:

1) Он вышел из класса (и его там больше нет) - perfective aspect.

2) Он выходил из класса (и, следовательно, не знает, что мы без него делали) - Imperfective Aspect.

It should be noted that in the examples of косил/скосил, вылиел/выходил the difference between the Perfective and Imperfective Aspect consists not only in keeping/not keeping the results, consequences of an action, but also the characteristics of these results: direct consequences are opposed to indirect, logically derivable consequences. 
As for the meaning of Pluperfect, it most often manifests itself in coherent narration in case of breakaway from the progressive moving of the main plot line. It can be expressed both by the past perfective and imperfective, for example:

Она похудела и подурнела, (и на улице встречные уже не глядели на неё, как прежде, и не ульббались ей) (А. Чехов).

На пороге стояла молодая женщина в черном платье. Очевидно она торопилась выйти к нему и плохо причесалась (К. Паустовский).

It should be noted that the perfect and pluperfect meanings of the Russian Past Tense forms are rather homogenious. Their demarcation, in our opinion, is due to the interaction of perfectness with other aspectual meanings of verb forms, the lexical meanings of verbs, context and speech situation.

Considering the aspectual semantics of the verbs of Imperfective and Perfective Aspects of the Russian language in this way, let's present the classification of the more vivid aspectual meanings of the verb, in relation to the tense-aspect forms.

Table 3

Tense-Aspect forms and the aspectual semantics of the Russian verb

\begin{tabular}{|l|c|c|c|c|c|c|c|}
\hline \multirow{2}{*}{ Form } & \multicolumn{5}{|c|}{ Meaning } \\
\cline { 2 - 7 } & $\begin{array}{l}\text { Limi- } \\
\text { tative- } \\
\text { ness }\end{array}$ & $\begin{array}{l}\text { Resul- } \\
\text { tative- } \\
\text { ness }\end{array}$ & $\begin{array}{l}\text { Process- } \\
\text { ness }\end{array}$ & Duration & $\begin{array}{l}\text { Multi- } \\
\text { plicity }\end{array}$ & $\begin{array}{l}\text { Phase- } \\
\text { ness }\end{array}$ & $\begin{array}{l}\text { Perfect- } \\
\text { ness }\end{array}$ \\
\hline $\begin{array}{l}\text { Past form } \\
\text { of the } \\
\text { imperfective } \\
\text { aspect }\end{array}$ & - & - & + & + & + & + & - \\
\hline $\begin{array}{l}\text { Present } \\
\text { form of the } \\
\text { imperfective } \\
\text { aspect }\end{array}$ & - & - & + & + & + & + & - \\
\hline $\begin{array}{l}\text { Future form } \\
\text { of the } \\
\text { imperfective } \\
\text { aspect }\end{array}$ & - & - & + & + & + & - & - \\
\hline $\begin{array}{l}\text { Past form } \\
\text { of the } \\
\text { perfective } \\
\text { aspect }\end{array}$ & + & + & - & - & + & - & + \\
\hline $\begin{array}{l}\text { Future form } \\
\text { of the } \\
\text { perfective } \\
\text { aspect }\end{array}$ & + & + & - & - & + & - & + \\
\hline
\end{tabular}

In accord with the markedness of the forms of the Perfective Aspect its functional-semantic range is more restricted and homogenious in comparison with the unmarked form of imperfective aspect. First of all, processness, duration and phaseness are being excluded, which is due to the categorial meanings of integrity 
and limitativeness, as for the possibility of multiplicity, evidently, is connected either with the definite Aktionsart: Poplakala-poplakala $i$ perestala, or with the external lexical determinants: Много раз приходил он сюда.

\section{Aspectuality of the English Verb}

The English verb has a rather developed system of Tense-Aspect forms, in which the main category is the category of Tense. The real time - the form of existing of matter - is in the constant move and continuously changes. Verb Tenses in real speech can reflect the real time, when the reference point is the real moment of utterance. But the verb tense forms reflect also relative time, in which the reference point doesn't coincide with the real moment of utterance, as a rule, in colloquial speech and in the works of fiction, in the narrative.

In the English language, the asymmetry of form and meaning in functioning of verb forms is revealed in that as if there is one unambiguous relevance, as the analytical forms fix more clearly regular grammatical meanings through auxiliary elements.

The relation with the moment of speech is essential for the verb forms, referring to the dynamic development of the action. But along with it there exist such forms, the function of which is the specification of the action in the definite temporal sphere, and not simply its dynamic development. If the action refers to the present, these forms are correlated with the present, actual moment of speech. If the specification expressed by them refers to the action in the past, it is correlated with the reference point in the past; it can be specially marked lexically or by other action, taking place at the given moment, but the immediate correlation with the moment of utterance isn't observed then. Let's turn to the examples:

As we drank (Past Indefinite) Brown's health, I caught (Past Indefinite) his dark, vigilant eye. He had tamed (Past Perfect) Winslow for the moment; he was showing (Past Continuous) Jago at his best... (Ch. Snow).

The forms had tamed and was showing do not develop the action in time, they are not dynamic; they specify the state of things, expressed by the verbs drank and caught, which are the indicators of the temporal centre, i.e. the reference point in the past.

In the Future Tense, the temporal centre is marked for the specifying forms also, but the correlation with it seldom occurs in the text due to the fact, that in the English language the functioning of the future tense forms is not characteristic of the detailed narratives.

The grammatical category of aspect is usually defined as a formal category, conveying the character of the development of action. The specific nature of the English aspectual forms consists in the fact, that the meaning of the verb is necessarily associated with the indication of the period of time, in which the action develops and, correspondingly, is expressed within the time, thus, a complicated Tense-Aspect category is often mentioned [19. P. 243]. 
Consequently, in the English language, Aspect is defined as a category, conveying the character of the development of action with reference to the moment or the period of time, indicated by the form. That is why the aspectual forms are called Tense-Aspect forms, in order to underline the inseparable connection of tense and aspect in English.

The English aspectual system is characterized by the existence of the three paradigmatically-structured Tense-Aspect subsystems: Common, Continuous (Progressive), Perfect. At the same time, like in the Russian language, voice and its forms are equally characteristic for all the paradigms of Tense-Aspect, and the significant internal structural opposition is the privative opposition Perfect - NonPerfect, the latter includes Common and partly Continuous, as there are forms and meanings for Perfect Continuous as well.

Let us illustrate the interaction of the main verb categories in the form of tables.

Table 4

Tense-Aspect forms of the English verb

A. Active Voice

\begin{tabular}{|l|l|l|l|l|}
\hline \multirow{2}{*}{ Perfect } & \multirow{2}{*}{ Aspect } & \multicolumn{3}{c|}{ Tense } \\
\cline { 3 - 5 } & \multicolumn{1}{|c|}{ Present } & \multicolumn{1}{c|}{ Past } & \multicolumn{1}{c|}{ Future } \\
\hline \multirow{3}{*}{ Non-perfect } & Common & $\begin{array}{l}\text { take } \\
\text { takes (3ps) }\end{array}$ & took & will take \\
\cline { 2 - 5 } & Continuous & $\begin{array}{l}\text { am taking } \\
\text { is taking } \\
\text { are taking }\end{array}$ & $\begin{array}{l}\text { was/were } \\
\text { taking }\end{array}$ & will be taking \\
\hline \multirow{3}{*}{ Perfect } & Common & $\begin{array}{l}\text { has/have } \\
\text { taken }\end{array}$ & had taken & will have taken \\
\cline { 2 - 5 } & Continuous & $\begin{array}{l}\text { has/have } \\
\text { been taking }\end{array}$ & had been taking & $\begin{array}{l}\text { will have been } \\
\text { taken }\end{array}$ \\
\hline
\end{tabular}

B. Passive Voice

\begin{tabular}{|c|c|c|c|c|}
\hline \multirow{2}{*}{ Perfect } & \multirow{2}{*}{ Aspect } & \multicolumn{3}{|c|}{ Tense } \\
\hline & & Present & Past & Future \\
\hline \multirow{2}{*}{ Non-perfect } & Common & $\begin{array}{l}\text { am } \\
\text { is taken } \\
\text { are }\end{array}$ & was/were taken & will be taken \\
\hline & Continuous & $\begin{array}{l}\text { am } \\
\text { is being taken } \\
\text { are }\end{array}$ & $\begin{array}{l}\text { was/were being } \\
\text { taken }\end{array}$ & $\begin{array}{l}- \\
\text { ( }{ }^{*} \text { will be being } \\
\text { taken) }\end{array}$ \\
\hline \multirow[b]{2}{*}{ Perfect } & Common & $\begin{array}{l}\text { has/have } \\
\text { been taken }\end{array}$ & had been taken & $\begin{array}{l}\text { will have been } \\
\text { taken }\end{array}$ \\
\hline & Continuous & $\begin{array}{l}- \\
\left({ }^{*} \text { has/have }\right. \\
\text { been being } \\
\text { taken) }\end{array}$ & $\begin{array}{l}- \\
\text { ( }{ }^{*} \text { had been } \\
\text { being taken) }\end{array}$ & $\begin{array}{l}- \\
\text { ( }{ }^{\star} \text { will have been } \\
\text { being taken) }\end{array}$ \\
\hline
\end{tabular}


It should be noted that all the forms marked with $(*)$ and bracketed are diachronically justified, but in the course of the development of the language the verb forms were maximally simplified, their semantic content changed, and besides, phonetically they were perceived ambiguously. Some forms were even lexicalized, compare: a) I had cut my hair. and b) I had my hair cut.

If in case of a) - it is typical Past Perfect, then in case of b) - it is «lexical Passive»: "somebody cut my hair», which is in practice checked by the procedure of using the reflexive like "myself" (in case of a)). Besides, let us note one more correlation: Simple - Continuous - Perfect, which is regularly presented in the practical grammar books of the English language, especially for English as a Second Language (E2L), for example, R. Murphy, Longman's, etc. First of all it clearly indicates to the form: simple or not, emphasizing, in this way the regularity of morphogenesis and analyticalness, characteristic of Continuous and Perfect, in the formation of which the auxiliaries of be и have takes part.

It is widely known, that Common form places the action in this or that period of time without any special aspectual characteristics: Common forms themselves are as if devoid of the aspectual meaning.

A.I. Smirnitski and B.A. Ilyish find, that the aspect meaning of the Common Aspect is extremely difficult to define, but for reasons of precision of the opposition of the Continuous Aspect they accept the necessity to consider the Common category as the form of the «common» aspect. B.A. Ilyish notes, that nonacceptance of aspect meaning of the Indefinite forms or the acceptance of «common» aspect confines, in fact, to the terminological discrepancy. In other word «Common» aspect and «no aspect» are the same, but for the sake of the symmetry of the opposition Common Aspect is ascribed aspect meaning, though so indefinite, that it is difficult to define it.

This view is not shared by a number of linguists for the reason, that in opposition to Tense-Aspect forms, - first with the Continuous Aspect, the aspectual meaning of which is recognized by the majority of linguists, an asymmetric correlation is revealed: only one of the forms is purely temporal, and it is opposed to other Tense-Aspect forms [21;22]. Thus, if Common Aspect is not complicated by the special aspectual meaning, then two other forms - Continuous and Perfect convey the aspectual meanings in close relation to the temporal meaning: they are- Continuous/Progressive and Perfect, including Perfect Continuous. In relation to Common Aspect they are the ways of the specification of the action, which successively and consistently are provided with analytical forms.

\section{Grammatical Category of Tense}

The grammatical category of Tense is peculiar to all the verb forms in the Indicative. Its basic meaning is «temporal locality», which allows to establish chronological conditionality and sequence in a text between the situations and events, and also in speech situations, which is especially actual for listener (reader).

In a language, the notion of Tense exists in two dimensions: 1) from the formal viewpoint this grammatical category is usually explicated in verb forms (although 
in language there exist both lexical and morphemic layers for indicating to the temporal relation or ordering); and 2) from the semantic point of view Tense serves to locate situations, state of things, processes, actions, etc. in time. At the same time, precedences and posteriorities, superposition and absorption (uptaking) some or other pieces of situations, as well as actions and processes, for example:

1. Tom has lost (Present Perfect) his key and now is looking for (Present Continuous) it. — i.e. first «lost», and now «is looking for» — precedence.

2. They are still working (Present Continuous) on the problem but haven't found the solution yet (Present Perfect). — «they are still working on the problem», but haven't found the solution yet» - superposition, combination. (Let us particularly note "still" and "yet" — signals, markers of verb forms and meanings).

Both dimensions of Tense - formal and semantic are in a constant interaction like form and meaning, although in the English language in comparison with the Russian language, there exist a considerably greater number of forms, and, consequently, the correlations «form-meaning», which are perceived automatically.

Immersing into the speech situation, Tense chooses some reference point, which is commonly referred to as «time of utterance». Usually, irrespectively of the language, time of utterance means the Present, i.e. fixes the coincidence with the situation of communication. The forms of the Tense, which refer to the "time of utterance», is commonly referred to as "absolute tenses", i.e. these forms appear with the meanings of Present, Past, Future as real mood forms, or Indefinite forms of the verb.

Correspondingly, relative tenses, or relative tense forms are determined contextually, do not have immediate connection with the «time of utterance». Most often such relativity can be found in the situation of Sequence of Tenses, when formal ordering takes place and appears such form, as Future-in-the-Past, for example, in indirect speech:

Richard said that he would come to see us next Monday.

In many languages including English, there are forms of Tense, in which both absolute and relative time are combined, which is governed by locating the situation in time. It refers, first of all, to Present Perfect, Present Continuous, Present Perfect Continuous, for which «time of utterance» (Present) is defined, but their semantics is conditioned by the specification of the state of things in speech situation with reference to time of utterance.

Let us illustrate this correlation schematically:

Table 5

Absolute and Relative Distribution of Tense

\begin{tabular}{|c|c|}
\hline Absolute Tense & Relative Tense \\
\hline Present Indefinite & Present Perfect \\
Present Continuous & Present Perfect Continuous \\
Past Indefinite & Past Perfect \\
Past Continuous & Past Perfect Continuous \\
\hline
\end{tabular}


Some scholars [21] find, that it should be more adequate to characterize such forms of tense as «absolute-relative», which first of all refers to Past Perfect (pluperfect) and Future Perfect, the latter provides, except the sequence of tenses, subjunctive mood «if...».

Thus, considering three possible ways of functioning of the category of Tense in the English language - absolute tense, relative tense, absolute-relative tense, let us point out their main semantic differences. If coincidence or correlation with the time of utterance (the Indefinite group) is characteristic of the absolute tense, then for the relative, including «absolute-relative» tenses precedence, posteriority, superposition on the time of utterance is characteristic. Such interaction is due to the specification of speech situation, locating of the given meanings of Tense in the situation of communication as a whole, and also the grammatical structure of tense forms - synthetic for absolute and analytical for relative ones. Besides, in the understanding and using of relative forms two semantic categories - Aspect и Aktionsart play a big role.

\section{Categories of Aspect and Aktionsart}

In the morphology of verb of various languages Aspect is grammatically considered together with the categories of Tense and Mood, for example in the Russian language aspectuality is based on the grammatical category of Aspect of verb, which interacts with the grammatical category of Tense of the verb, that's why Tense-Aspect verb forms or even Tense-Aspect system of verb is regularly discussed. Thus, the category of Aspect is realized in connection with the speech situation and communicative function of the speaker, who structure it.

In the broad sense, Aspect covers lexical and conceptual constituents of the verb, connected with the classification of speech situation, for which the term Aktionsart is used in Germanic philology (Comp. with «kinds of verb action» in the theory of functional grammar and in Russkaya grammatika (Praha, 1979) [23].

Traditionally for the English language two meanings of Aspect are distinguished: Common (B.A. Ilyish) and Continuous or Progressive. Perfect forms have indirect relation to aspect, as both mentioned meanings, on the one hand, realize themselves within Non-Perfect, correspondingly, Indefinite and Continuous, on the other hand - partially are represented also within Perfect, at least as Perfect Continuous. Then Perfect, according to a number of scholars [22; 15], appears a mixed category, which is suggested to name in a complicated way - Tense-Aspect, or refer it to Aktionsart.

More traditionally perfectiveness/imperfectiveness is interpreted as one of the central aspectual categories, as in many languages and verb systems it is more often expressed by the morphological means, though there aren't any universal means of expressing it [18. P. 243]. And even in one single language there isn't a distinct picture, at least because of the influence of diachronic factors on it. Compare: in the English language analytical form with the formal verb have corresponds to Perfect, 
in Russian - synthetic, rich in complicated meanings, though marked by the general meaning the form of the perfective aspect. Also owing to the synthetism of the Russian language the verb forms of the so-called «secondary imperfectivation» appear to be marked, for example, by the Russian suffix -iva/yva.

There are differences in the asymmetric organization of the system of verb forms of Tense in the Russian and English languages, mostly conditioned by the specifics of interaction with Aspect category (aspectuality). [24. P. 260-264]. In this respect it is necessary to pay attention to the fact, that in a language practice, including the practice of translation, synthetic forms of Common Aspect of the English language just like them appear grammatically unmarked, as The Russian verbs and partially the verbs of imperfective aspect. Such asymmetri is revealed for the Perfect in the form of Present Perfect and Past Perfect, which are marked with reference to the Indefinite form both by the form and by the meaning, at the same time, according to B. Comri, the latter appear «devoid of the meaning of time» (tenseless). As a conclusion it is suggested to consider the so-called «pure example», when perfectiveness/imperfectiveness in one of the verb systems of one of the possible languages serves as a dominant, without interacting with some other categories of Tense or Aspect. Thus, the most widespread viewpoint on the general meaning of perfect includes «integrity», «completeness», «limitativeness» [25;3].

Thus, if the category of Aspect in the English language is represented by the two privative oppositions: Perfect - Non-Perfect and within Non-Perfect Common - Continuous. The dimensionality of oppositions is accounted for the complex of meanings, which are characteristic of each of its members, and some meanings get close to the kinds of action (Aktionsart), especially if they have formal indicator of the distinctive semantic property. In this connection, undoubtedly, a question arises about the formal indicator. For the Russian language, typologically synthetic, such indicator, as a rule, appears the prefix or suffix within the word along with the possible lexical and contextual indicators, for example, adverbparticle yже, the collocation много раз and others. In the English language in case of the analytical form its organization unambiguously indicates to Aspect $и$ Aktionsart, which doesn't exclude the lexical and contextual specification, especially if necessary to choose:

Yesterday I received a letter (Common Aspect).

Recently I have received a letter (Perfect Aspect).

It is also interesting to note, that in case of Common и Continuous it's appropriate to complete every characteristic with the term "Non-Perfect", and in case of Perfect only partial clarification: Perfect Continuous. At the same time, in all the three cases the same possibility of the realization of the meanings of Tense is possible.

Thus, let us illustrate the described correlations on the scheme: 


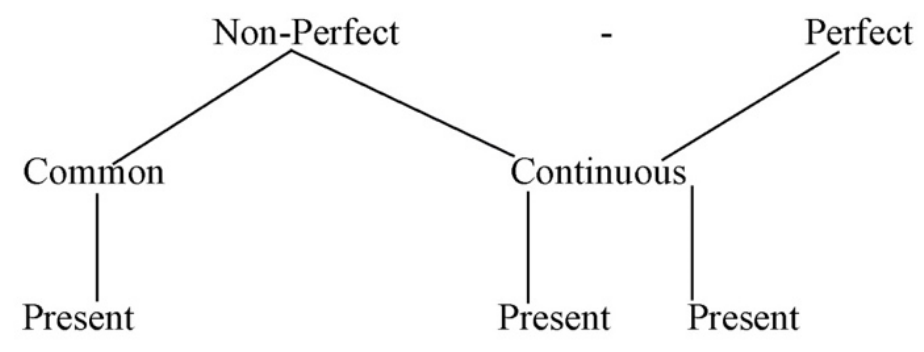

Past Past Present

Future $\quad(-) \quad(-)^{*}$

Scheme 1. Tense-Aspect Correlation

We have to remark that the Future Tense forms are eliminated as the are loaded with modal meanings of irreality and have some structural complexity, e.g.:

He $*_{\text {will be being training. }}$

He ${ }^{*}$ will have been being trained.

It should be noted, that Future forms aren't illustrated, because they are complicated by the modal meanings of unreality and excessive structural complications.

\section{Conclusion}

Despite the broad coverage of the phenomena of language and speech, highest priority is still given to the functioning of forms and categories, which are considered both within one, and two or more languages. The comparative study of the correlated forms and categories highlights the vivid, determining features of each language. In this respect, the categories and forms of the English Perfect, on the one hand, are included into the system and forms of the English verb, on the other hand - they reveal their specifics within the complex Tense-Aspect category.

In the Russian language, «perfectness» is correlated with the complex of the indicated aspectual meanings of the English Perfect. It is connected with the loss of the special Perfect form of verb in the Russian language and the reorganization not only formal, but also semantic structure of the verb as a class of words, as a part of speech. Besides, rather important for the Russian language is the category of aspect, which accumulates the aspectual meanings of the verb and appears in the form of the opposition «perfective aspect — imperfective aspect», correspondingly, «marked - unmarked» members of the opposition. The category of Aspect has allowed to identify aspectuality as a complex of kinds of action, which more concretely and unambiguously realize aspectual, to be more exact Tense-Aspect meanings. 
The comparison of the semantics of Aspect and Aktionsart in the Russian language with the semantics of English Perfect asymmetry is revealed, caused by cross-linguistic structural-typological differences, particularly, the existence or not the similar forms, their varying semantic load, anaytical or synthetic tendencies and others. The asymmetry is revealed especially vividly in the process of translation.

\section{Библиографический список}

1. Апресян Ю.Д. Избранные труды: монография. Т. 1. Лексическая семантика. М.: Школа «Языки русской культуры», 1995.

2. Мельчук И.А. Курс общей морфологии. Т. ІІ. Москва-Вена, 1998.

3. Бондарко А.В. Проблемы грамматической семантики и русской аспектологии. СПб.: Изд-во СПб. университета, 1996.

4. Шелякин М.А. Категория вида и способы действия русского глагола. (Теоретические основы). Таллин, 1983.

5. Якобсон Р. О структуре русского глагола // Избранные работы. Под ред. В.А. Звегинцева. М.: Прогресс, 1985. С. 210-221.

6. Русская грамматика: В 2-х томах. М.: Наука, 1980. Т. II. С. 563-680.

7. Булыгина T.В., Шмелев А.Д. Ментальные предикаты в аспекте аспектологии // Логический анализ языка. Проблемы интенсионального и прагмасемантического контекстов, Отв. ред. Н.Д. Арутюнова. М.: Наука, 1989. С. 22-26.

8. Маслов Ю.С. Глагольный вид в современном болгарском литературном языке. Значение и употребление // Вопросы грамматики болгарского литературного языка. М., 1959. C. $157-312$.

9. Исаченко А.В. Грамматический строй русского языка в сопоставлении со словацким. Морфология. Ч. ІІ. Братислава, 1960.

10. Шахматов А.А. Синтаксис русского языка. Л., 1941.

11. Гловинская М.Я. Семантические типы видового противопоставления русского глагола. М.: Наука, 1982.

12. Маслов Ю.С. Очерки по аспектологии. Л.: Наука, 1984.

13. Бульгина T.B. Классы предикатов и аспектуальная характеристика высказывания // Аспектуальные и темпоральные значения в славянских языках. М.: Наука, 1983. С. 15-19.

14. Кашпур В.В., Филь Ю.В., Шаповал А.А. Аспектуальные характеристики русского и английского глагола в языке и тексте. На материале повести М.А. Булгакова «Собачье сердце» // Вестник Томского государственного университета. 2013. no 377. С. 22-29.

15. Comrie B. Aspect. An Introduction to the study of verbal aspect and related problems. Cambridge: Cambridge University Press, 1976.

16. Теория функциональной грамматики: Введение. Аспектуальность. Временная локализованность. Таксис, сост. А.В. Бондарко, М.А. Шелякин, др. Л.: Наука, 1987.

17. Князев Ю.П. Результатив, пассив и перфект в русском языке // Типология результативных конструкций. Л.: Наука. 1983. С. 140-160.

18. The Encyclopedia of Language and Linguistics. N.Y., Seoul, Tokyo, 1994. Vol. 10. P. 243-265.

19. Ильиш Б.А. Строй современного английского языка (теоретический курс). М. 一Л.: Просвещение, 1965.

20. Смирниџкий А.И. Очерки по сопоставительной грамматике русского и английского языков. М.: Высшая школа, 1970.

21. Comrie B. Tense. Cambridge: Cambridge Univ. Press, 1986.

22. Dahl Ö. Tense and Aspect Systems. Oxford, 1989.

23. Русская грамматика: В 2-х томах. / Отв. ред. К. Горалек. Praha: ACADEMIA, 1979. T. 1. C. 24-242. 
24. Широкова Е.Н., Кошкарова Н.Н. Видо-временные значения английского и русского глагола через призму лингводидактики и лингвокультурологии // Вестник Нижегородского университета им. Н.И. Лобачевского. 2017. № 5. С. 260-264.

25. Телин Н., Нильс Б. Вид и способ действия в русском языке // Новое в зарубежной лингвистике. Вып. 15. М., 1985. С. 250-260.

\section{References}

1. Apresyan, Yu.D. (1995). Selected works: monograph. Vol. 1. Lexical semantics. Moscow: Shkola «Yazyki russkoj kul'tury». (In Russ.).

2. Mel'chuk, I.A. (1998). A course of general morphology. Vol. II. Moscow-Vienna. (In Russ.).

3. Bondarko, A.V. (1996). The problems of grammatical semantics and Russian aspectology. St. Petersburg: Izd-vo St. petersburgskogo universiteta. (In Russ.).

4. Shelyakin, M.A. (1983). The category of aspect and kinds of action of the Russian verb. (Theoretical bases). Tallin. (In Russ.).

5. Yakobson, R. (1985). On structure of the Russian verb In R. Yakobson. Selected works. Pod red. V.A. Zvegintseva. Moscow: Progress. 210-221. (In Russ.).

6. Russian grammar: in 4 vols. (1980). Moscow: Nauka. Vol. 1. pp. 563-680. (In Russ.).

7. Bulygina, T.V. \& Shmelyov, A.D. (1989). Mental predicates in terms of aspectology. Logical analysis of language. The problems of intentional and pragmasemantic contexts. Editor-in-chief N.D. Arutyunova. Moscow: Nauka. pp. 22-26. (In Russ.).

8. Maslov, Yu.S. (1959). Verbal aspect in contemporary bulgarian literary language. Meaning and use In Problems of grammar of bulgarian literary language. Moscow. pp. 157-312. (In Russ.).

9. Isachenko, A.V. (1960). Grammatical system of the Russian language in comparison with Slovene. Morphology. Part. II. Bratislava. (In Russ.).

10. Shakhmatov, A.A. (1941). Syntax of the Russian language. Leningrad. (In Russ.).

11. Glovinskaya, M.Ya. (1982). Semantic types of the aspectual opposition of the Russian verb. Moscow: Nauka. (In Russ.).

12. Maslov, Yu.S. (1984). Studies in aspectology. Leningrad: Nauka. (In Russ.).

13. Bulygina, T.V. (1983). Predicate classes and the aspectual characteristics of utterance In Aspectual and temporal meanings in Slavic languages.. Moscow: Nauka. pp. 15-19. (In Russ.).

14. Kashpur, V.V., Fil', Yu.V. \& Shapoval, A.A. (2013). Aspectual characteristics of the Russian and English verb in language and text. On the material of M.A. Bulgakov's novella «The heart of a dog». Tomsk State University Journal, 377, 22-29. (In Russ.).

15. Comrie, B. (1976). Aspect. An Introduction to the study of verbal aspect and related problems. Cambridge: Cambridge University Press.

16. Bondarko, A.V. \& Shelyakin, M.A. (1987) Theory of functional grammar: Introduction. Aspectuality. Temporal localization. Taxis. Leningrad: Nauka. (In Russ.).

17. Knyazev, Yu.P. (1983). The resultative, passive and perfect in the Russian language. The typology of the resultative constructions. Leningrad: Nauka. pp. 140-160. (In Russ.).

18. The Encyclopedia of Language and Linguistics. (1994). New York, Seoul, Tokyo. Vol. 10. pp. $243-265$.

19. Ilyish, B.A. (1965). The system of the contemporary English language. (Theoretical course). Moscow: Leningrad: Prosveshcheniye. (In Russ.).

20. Smirnitskij, A.I. (1970). Studies in comparative grammar of the Russian and English languages. Moskow: Vysshaya shkola. (In Russ.).

21. Comrie, B. (1986). Tense. Cambridge, etc.: Cambridge Univ. Press.

22. Dahl, Ö. (1989). Tense and Aspect Systems. Oxford.

23. Goralek, K. (1979). Russian grammar: in 2 vols. Praha: ACADEMIA. Vol. 1. pp. 24-242. 
24. Shirokova, E.N. \& Koshkarova, N.N. (2017). Tense-aspect meanings of English and Russian verb through linguodidactics and linguoculturology. Nizhegorod University after N.I. Lobachevski Journal, 5, 260-264. (In Russ.).

25. Telin, N. \& Nil's, B. (1985). Aspect and kinds of actions in the Russian language In New in foreign linguistics. Vol. 15. Moscow. pp. 250-260. (In Russ.).

\section{Сведения об авторе:}

Дериакян Рипсиме Альбертовна, кандидат филологических наук, старший преподаватель кафедры английского языка факультета русского и иностранного языков Ереванского государственного университета языков и социальных наук им. В.Я. Брюсова; сфера научных интересов: семантические исследования языка, контрастивный и сравнительный языковой анализ; e-mail: d-ripsime@mail.ru.

\section{Information about the author:}

Hripsime A. Derdzakyan, Candidate of Philology, Senior Lecturer of the General English Department, Russian and Foreign Languages Faculty, Yerevan State University of Languages and Social Sciences. The sphere of research includes semantic language studies, contrastive and comparative linguistic analyses; e-mail: d-ripsime@mail.ru. 